\title{
Research on Brand Value Evaluation Methods of Catering Enterprises
}

\author{
Wufang $^{\mathrm{a}}$, CaiHuali ${ }^{\mathrm{b}}$, Kangjian $^{\mathrm{c}}$, Duanqi $^{\mathrm{d}}$ \\ Quality Management Branch, China National Institute of Standardization, Beijing, China

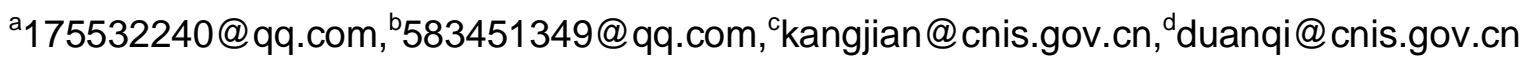

Key words: brand value evaluation, catering enterprises, Multi-cycle Excess Earnings Method Abstract:Brand reflects the comprehensive competitiveness of an enterprise and even a country. Brand value evaluation is a very important work in every country. There are three perspectives, namely financial affairs, brand based market power and consumers. We made a comparison of the three perspectives. We put forward the Multi-cycle Excess Earnings Method and made a clear description. At last, we use the method in the catering enterprises.

\section{Introduction}

Brand reflects the comprehensive competitiveness of an enterprise and even a country, and brand buildingrelates to the social development and economic transformation and upgrading of a country. Brand value decides the positionof different countries in the global industry value chain ${ }^{[1]}$. Brand is mainly valuated from three perspectives, namely financial performance, brand based market power and consumers. The opinion based on financial performance, by focusing on economic or financial model, accurately estimates brand value ${ }^{[2]}$ as basis for brand performance assessment or reflects brand value on financial statements from the viewpoint of accounting and provides reference for corporate mergers and acquisitions (M\&A) and clearing. The brand value based on financial performanceis regarded as main basis for estimate of brand value by some reputed brand listing organizations including Forbes; The opinion based on market power deepens the idea based on financial brand value ${ }^{[3]}$ and believes that the financial value of a brand is realized by its market influence and market power. It remains to evaluate brand value from the perspective of enterprises and represents an important aspect to be considered by some reputed brand valuation organizations including Interbrand;Thebrand valuationfrom the perspective of consumers represents a prevailing idea held by the current marketing academia ${ }^{[4]}$ and reflects the intangible value of brands. The idea reflects the intangible value of a brand and provides a targeted reference from the behavior level for brand development strategies of enterprises as it gets to the root of brand value, i.e. consumer recognition. However, the largest limit of the idea is that brand valuation indexes are excessively subjective and are difficult to represent brand value in a quantitative manner.

\section{Multi-cycle Excess Earnings Method}

\section{A. Multi-cycle Excess Earnings Method Model}

The corporate or corporate group brand value based on multi-cycle excess earnings method is calculated according to the following Equation (1):

$$
V_{B}=\sum_{t=1}^{T} \frac{F_{B C, t}}{(1+R)^{t}}+\frac{F_{B C, T+1}}{(R-g)} \bullet \frac{1}{(1+R)^{T}} \ldots \ldots \ldots \ldots \ldots \ldots \ldots
$$

Where:

$V_{B}$ means brand value;

$\mathrm{F}_{\mathrm{BC}, \mathrm{t}}$ means brand cash flow in Year $\mathrm{t}$;

$\mathrm{F}_{\mathrm{BC}, \mathrm{T}+1}$ means brand cash flow in Year $\mathrm{T}+1$; 
T means high-growth period, normally 3 to 5 years, depending on industry characters;

$\mathrm{R}$ means discount rate of brand value;

g means perpetual growth rate; long-term expected inflation rate may be used.

\section{B. Determination of Brand Cash Flow}

\section{B.1 Brand Cash Flow}

The brand cash flow of each year is calculated according to the following Equation (2):

$$
F_{B C}=\left(P_{A}-I_{A}\right) \times \beta
$$

Where:

$\mathrm{F}_{\mathrm{BC}}$ means brand cash flow of the current year;

$\mathrm{P}_{\mathrm{A}}$ means net profits of an enterprise after adjustment in the current year; non-recurring business items may be considered if applicable;

$\mathrm{I}_{\mathrm{A}}$ means tangible asset income of an enterprise in the current year;

$\beta$ means proportion factor attributed to brand in the intangible asset income of an enterprise.

Whenforecast brand cash flow during a high-growth period and in a longer term, the cash flow of brand in three to five years before the reference year may be adopted.

\section{B.2 Determination of Tangible Asset Income}

\section{B.2.1 Tangible asset income}

Tangible asset income shall be calculated according to Equation (3):

$$
I_{A}=A_{C T} \times \beta_{C T}+A_{N C T} \times \beta_{N C T}
$$

Where,

$\mathrm{I}_{\mathrm{A}}$ means tangible asset income;

$\mathrm{A}_{\mathrm{CT}}$ means total amount of current tangible asset;

$\beta_{C T}$ means rate of return on investment of current tangible asset;

$\mathrm{A}_{\mathrm{NCT}}$ means total amount of noncurrent tangible asset;

$\beta_{N C T}$ means rate of return on investment of noncurrent tangible asset.

\section{B.2.2 Income rate of current tangible asset}

For income rate of current tangible asset, refer to the short-term benchmark lending rate announced by the People's Bank of China for calculation, one year, for example.

\section{B.2.3 Income rate of noncurrent tangible asset}

For income rate of noncurrent tangible asset, refer to the long-term benchmark lending rate announced by the People's Bank of China for calculation, five years, for example.

\section{B.3 Determination of Brand Value Discount Rate}

\section{B.3.1 Brand value discount rate}

Brand value discount rate shall be calculated according to the following Equation (4):

$$
R=Z \times K
$$

Where,

$\mathrm{R}$ means brand value discount rate;

$\mathrm{Z}$ means average asset return rate of the industry;

$\mathrm{K}$ means brand strength coefficient.

\section{B.3.2 Average asset return rate of the industry}

The average asset return rate of the industry may be obtained by calculating the average asset return rate of listing enterprises of similar industries, types and scales or by statistics and survey.

\section{B.3.3 Brand strength coefficient}

Brand strength coefficient is composed of first-level indexes including organizational behavior $\left(\mathrm{K}_{1}\right)$, customer relations $\left(\mathrm{K}_{2}\right)$, market status $\left(\mathrm{K}_{3}\right)$ and legal rights and benefits $\left(\mathrm{K}_{4}\right)$ and may be calculated according to the following Equation (5): 


$$
K=\sum_{i=1}^{4} K_{i} \times W_{i}
$$

Where,

$\mathrm{K}$ means brand strength coefficient;

$\mathrm{K}_{\mathrm{i}}$ means valuated value of the first-level index $\mathrm{i}$;

$\mathrm{W}_{\mathrm{i}}$ means the weight of influence of the first-level index $\mathrm{i}$.

If organizational behavior $\left(\mathrm{K}_{1}\right)$, customer relations $\left(\mathrm{K}_{2}\right)$, market status $\left(\mathrm{K}_{3}\right)$ and legal rights and benefits $\left(\mathrm{K}_{4}\right)$ are composed of second-level indexes, brand strength coefficient may be calculated according to the following Equation (6):

$$
K_{i}=\sum_{j=1}^{j} K_{i j} \times W_{i j}
$$

Where,

Ki means score of the first-level index i;

$K_{i j}$ means valuated value of the second-level index $\mathrm{j}$ under the first-level index $\mathrm{i}$;

$\mathrm{W}_{\mathrm{ij}}$ means weight of influence of the second-level index $\mathrm{j}$ on the first-level index $\mathrm{i}$.

According to the actual conditions of Chinese enterprises and market, a specific conversion method was used to limit brand strength coefficient to a scientific scope, such as [0.6, 2].

\section{B.3.4 Brand strength coefficient index system Indexes concerning organizational behavior}

Organizational behavior $\left(\mathrm{K}_{1}\right)$ is composed of three second-level indexes including quality advancement $\left(\mathrm{K}_{11}\right)$, innovation capability $\left(\mathrm{K}_{12}\right)$ and brand building $\left(\mathrm{K}_{13}\right)$.

\section{Indexes concerningcustomer relations}

The indexes concerning customer relations $\left(\mathrm{K}_{2}\right)$ may include:

-Brand image;

-Customer satisfaction;

-Brand loyalty, etc.

\section{Indexes concerning market status}

The indexes concerning market status $\left(\mathrm{K}_{3}\right)$ may include:

-Leading status of an enterprise or enterprise group in the industry;

-Brand awareness;

-Development of international market;

-Brand history, etc.

\section{Indexes concerning legal rights and interests}

The indexes concerning legal rights and interests $\left(\mathrm{K}_{4}\right)$ may include:

-Whether the industry is encouraged by the State;

-Participation in the formulation of local, industry, national and international standards;

-Granting of reputed trademark, (provincial) famous Chinese brand, China's time-honored brand, etc.

-Issuing of certificates including geographical indication product and place of origin;

-Whether the brand falls into the scope of reputed brand building demonstration area;

-Protection of intellectual property such as registered trademark, copyright and technological achievement right;

-Traditional knowledge and inherited resources, etc.

\section{Application}

The multi-cycle excess earnings method was applied in some enterprises. The result of application is shown in the following table: 


\begin{tabular}{|l|c|c|c|}
\hline \multicolumn{1}{|c|}{ Enterprise Name } & $\begin{array}{c}\text { Brand } \\
\text { Strength } \\
\text { (Maximum } \\
\text { for 1000) }\end{array}$ & $\begin{array}{c}\text { Brand Value } \\
\text { (Ten Thousand Yuan) }\end{array}$ & $\begin{array}{c}\text { Brand Value } \\
\text { (Hundred Million Yuan) }\end{array}$ \\
\hline Meizhou Dongpo Group & 921.33 & 317174.13 & 31.72 \\
\hline $\begin{array}{l}\text { Beijing Jinfeng Catering Co., } \\
\text { Ltd. }\end{array}$ & 908.67 & 228263.64 & 22.83 \\
\hline $\begin{array}{l}\text { Xiao Nan GuoRestaurants } \\
\text { Holdings Limited (XNG) }\end{array}$ & 920.67 & 211781.68 & 21.18 \\
\hline $\begin{array}{l}\text { Beijing Jinbaiwan Entertainment } \\
\text { Co., Ltd. }\end{array}$ & 883.00 & 144286.24 & 14.43 \\
\hline $\begin{array}{l}\text { Zhejiang C. Straits Food Chain } \\
\text { Co., Ltd. }\end{array}$ & 162.67 & 143205.78 & 14.32 \\
\hline Shandong Kerry Catering Group & 884.67 & 141383.12 & 2.24 \\
\hline $\begin{array}{l}\text { Beijing Porridge Jiahe Enterprise } \\
\text { Management CO. LTD. }\end{array}$ & 840.00 & 22370.39 & 2.14 \\
\hline $\begin{array}{l}\text { Beijing Hehegu Catering } \\
\text { Management Co., Ltd. }\end{array}$ & 876.67 & 21397.06 & 0.85 \\
\hline $\begin{array}{l}\text { Zhejiang Yanzhoufu Food Co., } \\
\text { Ltd. }\end{array}$ & 860.67 & 8539.07 & \\
\hline
\end{tabular}

\section{References}

[1] Chematony, L. D.; McWilliam, G. Branding Terminology: The Real Debate [J]. Marketing Intelligence and Planning, 1989 (17): 29 - 32.

[2] Simon, C. J. and Sullivan, M. W. The Measurement and Determinants of Brand Equity: A Financial Approach [J]. Marketing Science, winter., 1993: 1 - 13.

[3] Huang Changfu. Brand Competition: System Competition under Buyer's Market Conditions. China Business and Market, 1999 (3): 18-20.

[4] Keller, K. L. Conceptualizing, Measuring and Managing Customer-based Brand Equity [J]. Journal of Marketing, 1993, 57(1):1-22. 